\title{
Etnopedagogi: Tinjauan Aktualisasi \\ Merdeka Belajar Dalam \\ Konstruksi Sikap Sosial
}

\section{Putu Sabda Jayendra \\ Institut Pariwisata dan Bisnis Internasional}

Merdeka belajar pada hakikatnya memiliki esensi konstruktivistik. Konsep belajar konstruktivistik saat ini dipandang sebagai pola yang mampu mengintegrasikan tujuan pembelajaran. Belajar konstruktivisme merupakan pola dimana peserta didik secara aktif mengkonstruksi sendiri pengetahuannya melalui belajar yang menyenangkan. Penekanan konstruktivistik pada dasarnya terletak pada pembelajar yang mengkonstruksi realitasnya sendiri atau paling tidak menafsirkannya berdasarkan pada persepsi-persepsi pengalaman.

Melalui pola belajar konstruktivistik, peserta didik mampu menciptakan pengetahuan yang bersifat long term memory. Hal ini karena dari pengalaman belajar yang aktif dikonstruksi sendiri, disertai dengan kesan yang menyenangkan akan menciptakan ingatan yang 
bertahan lama, bahkan permanen. Kebebasan peserta didik dieksplorasi dalam upaya pemahaman sekaligus pengembangan cakupan penguasaan materi pembelajaran. Terlebih dalam level pendidikan tinggi, pengalaman di lapangan dan materi yang diperoleh di bangku kuliah wajib dikomparasikan, diintegrasikan, dan diimplementasikan dalam

kehidupan bermasyarakat secara lebih intensif.

Salah satu bentuk aktualisasi pembelajaran konstruktivistik adalah etnopedagogi. Etnopedagogi adalah menggali berbagai unikum kearifan lokal (local genius) beserta nilai-nilai budaya yang terkandung di dalamnya. Etnopedagogi adalah praktik pendidikan berbasis kearifan lokal dalam berbagai ranah. Tujuannya agar pembelajaran yang diupayakan tetap dapat selaras dengan nilai-nilai sosio-kultural yang dianut dalam komunitas masyarakat.

Pendidikan pada hakikatnya merupakan proses transformasi budaya. Salah seorang tokoh konstruktivistik, Vygotsky mengemukakan bahwa masa belajar dimulai ketika individu dalam perkembangan yang disebut Zone Proximal, yaitu suatu tingkat yang dicapai ketika 
melakukan perilaku sosial. Individu akan belajar mengenai berbagai konsep paling baik apabila konsep itu berada dalam zona perkembangan terdekat mereka. Zone Proximal juga dapat diartikan bahwa seorang pembelajar tidak dapat melakukan sesuatu sendiri, namun memerlukan bantuan kelompok sosial.

Belajar konstruktivistik melalui praktik etnopedagogi dapat membantu peserta didik dalam mengimplementasikan pengetahuannya dan membentuk sikap sosialnya di tengah kondisi real masyarakat. Terlebih kecenderungan generasi muda dewasa ini yang mengindikasikan semakin individualistis dan tercerabut dari akar budaya yang adiluhung. Dengan demikian, diharapkan pembelajaran yang diupayakan dapat menciptakan insan cerdas, berbudaya, dan berkarakter, selaras dengan nilai-nilai yang dianut dalam komunitas masyarakatnya.

\section{Konstruksi Sifat Interaktif}

Aktualisasi etnopedagogi dalam kaitannya dengan konstruksi sifat interaktif, artinya konstruksi sifat sosial dalam kaitannya dengan kemampuan berinteraksi, aktif membangun komunikasi antar-sesamanya. Pada hakikatnya 
suatu proses interaksi terjadi jika individu dihadapkan dengan individu lainnya, atau berada dalam suatu kelompok komunitas sosial masyarakat. Interaksi-interaksi akan lebih intens terjadi jika dalam suatu pranata sosial individu memegang peranan tertentu yang dituntut bersinergi dengan peranan yang lainnya.

Dalam hal ini, aktualisasi belajar konstruktivistik melalui etnopedagogi merupakan suatu kombinasi yang tepat dalam membentuk sifat interaktif. Suatu contoh dalam kearifan lokal sosial masyarakat Bali dikenal adanya organisasi kepemudaan yang disebut Sekaa Teruna-Teruni sebagai bagian integral dari kesatuan desa adat. Dalam hal ini para pemuda dan gadis-gadis mengambil peranan secara aktif dalam kegiatan sosial adat istiadat, rajin berkoordinasi dengan para tetua, sekaligus mempersiapkan diri sebagai penerus nilai-nilai kearifan lokalnya.

Dalam hal ini, para peserta didik secara langsung, disadari atau tidak diarahkan untuk cermat dalam berinteraksi, memilih dan memilah tata bahasa, dan pandai menafsirkan situasi. Sangat relevan dengan pernyataan Vgotsky bahwa pembelajar akan lebih baik tidak belajar dalam isolasi. Sebaliknya belajar sangat 
dipengaruhi oleh interaksi sosial dalam konteks yang bermakna. Interaksi sosial dengan yang lebih berpengalaman akan turut memperkuat kesan belajar dan proses transformasi budayapun akhirnya dapat terwujud sesuai yang diharapkan.

\section{Konstruksi Tanggung Jawab Moral}

Tanggung jawab moral merupakan unsur sikap kepribadian yang wajib diimplementasikan dalam proses pendidikan. Tanggung jawab moral sebagai bagian dari pembentukan mentalitas setiap individu yang pada akhirnya terakumulasi menjadi karakteristik suatu komunitas. Tanggung jawab moral juga akan menentukan tingkat solidaritas individu dalam kehidupan masyarakat.

Tanggung jawab moral akan diperoleh manakala peserta didik mendapatkan tugastugas sosial. Aspek-aspek yang membangun komponen tanggung jawab moral akan diperkuat, yang diantaranya adalah; 1) toleransi, 2) kesesuaian (harmoni), 3) simpati, 4) welas asih, 5) keseimbangan, 6) kasih sayang, 7) kesabaran, 8) ketabahan, 9) kerendahan hati, 
10) kedermawanan, 11) kemuliaan, 12) kendali diri, 13) kejujuran, dan 14) integritas.

Belajar tanggung jawab moral tentunya menawarkan konsekuensi yang tidak menyenangkan (negative reinforcement atau punishment) jika tugas yang dikerjakan tidak sesuai harapan. Dalam hal ini masyarakatlah yang bertindak selaku pengontrol dan evaluatornya. Hal ini akan berimplikasi pada timbulnya kecenderungan individu pembelajar untuk menghindari pilihan yang tidak menyenangkan tersebut, sehingga akan diupayakan semaksimal mungkin memenuhi tugas-tugas yang dibebankan kepadanya.

\section{Konstruksi Sikap Demokratis}

Sikap demokratis diartikan sebagai sikap saling menghargai kendati pendapat satu sama lain berbeda. Masing-masing individu belajar mengemukakan pendapat, dan saling memberi ruang untuk mengemukakan pandangan. Dalam menanamkan sikap demokratis, peserta didik diberi kesempatan untuk memberikan tanggapan, pendapat, dan penilaian terhadap nilai-nilai yang ditemukan. 
Sikap demokratis terdiri dari komponen antara lain; 1) keterbukaan, 2) kejujuran, 3) penghargaan terhadap pendapat orang lain, dan 4) toleransi. Sikap demokratis sangat diperlukan untuk membangun tatanan masyarakat yang aktif berpartisipasi dalam berbagai aspek bidang pembangunan, serta mengandung unsur-unsur moral. Sikap demokratis juga merupakan sebuah pandangan hidup dalam membentuk suatu konsensus dalam masyarakat sehingga menjadi nilai-nilai yang dijunjung bersama.

Konstruksi sikap demokratis melalui pembelajaran etnopedagogi, musyawarah mufakat merupakan contoh media belajar yang tepat melalui kondisi real di masyarakat. Dalam hal ini, para peserta didik diajarkan untuk mendengar, berbicara, mengkompilasi berbagai pendapat yang masuk, serta menalar untuk mencari titik temu setiap perbedaan. Keterbukaan, netralitas, mengesampingkan ego pribadi akan dibiasakan untuk menghasilkan pribadi yang jujur dan bijaksana.

\section{Konstruksi Sikap Kooperatif}

Sikap kooperatif merupakan sikap mau bekerjasama antar-individu dalam kelompok 
sebagai satu kesatuan yang utuh. Penanaman sikap kooperatif didasari falsafah bahwa manusia adalah makhluk sosial. Kerja sama merupakan kebutuhan penting artinya bagi kelangsungan hidup manusia. Tanpa kerja sama, kehidupan manusia akan punah. Karena itu, mindset yang harus ditanamkan adalah orang lain merupakan kawan untuk diajak bekerja sama, bukan lawan yang harus dikalahkan.

Dalam tinjauan konstruktivisme, hakikat dari kebersamaan dan kerjasama yang senantiasa dilakukan merupakan pengimplementasian cooperative learning. Peserta didik akan lebih mudah menemukan secara komprehensif konsep-konsep yang sulit dipahami realitasnya dibandingkan dengan belajar individual. Terlebih berada pada situasi di masyarakat yang real, maka kerjasama sebagai kesatuan kelompok akan diperkuat dalam rangka mengeksplorasi dan menantang pengetahuan yang dimiliki.

Salah satu ciri pembelajaran kooperatif adalah spesialisasi tugas. Disamping merupakan bagian dari konstruksi tanggung jawab moral, hal ini juga menjadi bagian dari penanaman mindset bahwa keberhasilan dari penyelesaian 
tugasnya akan menunjang keberhasilan individu lainnya, sehingga menyadari bahwa dirinya adalah bagian dari sistem (team). Dengan menyadari hal tersebut, para peserta didik akan belajar memperhitungkan situasi dan kondisi dengan cermat, tidak bertindak sendiri-sendiri atau kurang perhitungan, yang akan berdampak buruk bagi kesatuan kelompok. Bahkan dengan menyadari hal tersebut, setiap individu yang telah menyelesaikan tugasnya akan berkenan membantu tugas-tugas lainnya yang belum tuntas.

Semua komponen sikap sosial yang telah dipaparkan tersebut (interaktif, tanggung jawab moral, demokratis, dan kooperatif) secara keseluruhan merupakan unsur yang menjadi konstruksi bangunan solidaritas sosial. Dalam menjaga eksistensi suatu komunitas masyarakat yang beradab serta berbudaya, solidaritas sosial merupakan hal yang mutlak diperkuat. Implementasi pembelajaran konstruktivistik melalui aktualisasi etnopedagogi dengan sendirinya akan mengurangi potensi-potensi konflik di masyarakat. Hal inilah yang dalam pandangan Vygotsky disebutkan bahwa lingkungan sosial mempengaruhi kognisi atau 
pola pemikiran dan kesadaran masing-masing individu melalui objek kultural. Proses pewarisan budaya dan sosialisasi nilai melalui kearifan lokal pada akhirnya akan memperkuat identitas masyarakat yang cerdas dan berkarakter.

(Naskah ditulis di Denpasar, 2 Juli 2020) 
169 | B o ok Chapter

BIODATA PENULIS 


\section{Putu Sabda Jayendra}

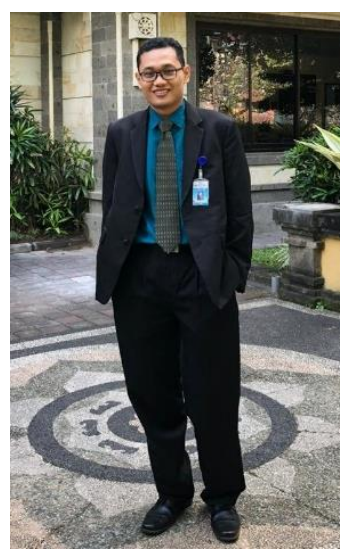

Dr. Putu Sabda Jayendra, M.Pd.H. lahir di Singaraja, Buleleng, Bali pada tanggal 14 Agustus 1987. Merupakan putra pertama dari tiga bersaudara pasangan suami-istri Drs. I Made Nuada, M.Pd. dan Ni Ketut Suryaning. Menamatkan pendidikan Taman KanakKanak di TK Mutiara Singaraja tahun 1993, Sekolah Dasar di SD Negeri 2 Banyuasri, Singaraja hingga kelas 4, (karena mengikuti orang tuanya pindah tugas) dan melanjutkan sekolahnya di SD Negeri 2 Pekutatan, Jembrana hingga tamat tahun 1999. Selanjutnya menempuh Sekolah Lanjutan Tingkat Pertama di SLTP Negeri 1 Pekutatan (SMP Negeri 1 Pekutatan), Jembrana dan tamat tahun 2002. Sekolah Menengah Atas ditempuhnya di SMA Negeri 1 Pekutatan hingga kelas 2 (karena mengikuti orang tuanya kembali pindah tugas) dan melanjutkan sekolahnya di SMA Negeri 1 Mendoyo, Jembrana hingga tamat tahun 2005. Jenjang S1 - S3 ditempuhnya di Institut Hindu Dharma Negeri Denpasar dengan bidang kajian Pendidikan dan Ilmu Agama Hindu. Dr. Putu Sabda Jayendra, M.Pd.H. merupakan penulis yang aktif membuat karya-karya publikasi ilmiah serta menulis buku. Sebagian besar karyanya mengeksplorasi tentang praktik pendidikan dalam tradisi keagamaan dan kearifan lokal (etnopedagogi). Saat ini aktif tercatat sebagai Dosen Tetap di Institut Pariwisata dan Bisnis Internasional di Denpasar Bali, serta aktif pula menjadi Dosen Luar Biasa di beberapa Perguruan Tinggi lainnya. Dalam kegiatan bidang sosial budaya juga turut aktif, diantaranya pada tahun 2020 sebagai Assessor Tri Hita Karana Awards dan menjabat sebagai Wakil Ketua I Perhimpunan Hubungan Masyarakat Indonesia (PERHUMAS) BPC Denpasar. 